\title{
Construction of Speculative Thinking Ability and Exploration on Multi-training Model in Business English Teaching
}

\author{
Ling Zhang \\ Heihe University \\ Heihe, China 164300
}

\begin{abstract}
At present, our colleges and universities have gradually set up the major of Business English. Our teaching system becomes more and more perfect. However, most of Business English teachings are traditional. With indefinite teaching goal and fuzzy positioning, divergence of theory and practice, there are many problems in Business English teaching. Therefore, it is very necessary to use current excellent theories and models to construct a new class system based on speculative thinking ability multi-training target for Business English to solve these problems.
\end{abstract}

Keywords-Business English; training of speculative thinking ability; multi-training; construction of new classroom teaching

\section{INTRODUCTION}

In recent years, the training of speculative thinking ability is increasingly concerned by higher education circles. It is beset with many difficulties to study. The speculative thinking ability, also called critical thinking ability, refers to the ability of a person to make rational judgment by using appropriate evaluation criteria and conscious thinking in order to decide the real value of something. The Long-term National Education Reform and Development Plan (2010 2020) clearly pointed out that it is very necessary "to promote all-round development of students, to improve students' sense of social responsibility to serve the country and the people, to improve students' innovative and exploring spirits and practical ability to solve problems"1 in order to develop education in the long run. Therefore, to cultivate and develop the students' critical thinking ability is the obligatory responsibility of educators and a strategic task for our long-term development.

\section{The TeAching Situation OF Business ENGLish}

In 2007, China's Ministry of Education officially approved the major of Business English for undergraduate. It belongs to one of foreign language majors, same like other traditional English majors (English and American Literature, Linguistics

Fund project: Educational Science Planning Topic of Heilongiiang Province; Research on Construction of Speculative Thinking Ability MultiTraining Model in Business English Teaching (GJ1215039)).

${ }^{1}$ Medium and Long-term National Education Reform and Development Plan (Year), National Outline for Medium and Long-term Education Reform and Development Plan (2010 2020). Ningxia Education, 2010(Z3): 13-37. and Introduction to Britain and America). As of 2009, the Ministry of Education has approved seven universities, including University of International Business and Economics, to set up the major of Business English for undergraduate. Nearly 700 colleges and universities have set up the major of Business English. Some domestic colleges and universities not only recruit undergraduates and double-degree students, but also recruit graduate students for Business English. However, the positioning of Business English is not clear. In most colleges and universities, Business English is arranged inside the school of foreign languages, as a branch of English majors. It doesn't develop into an independent discipline, so students get certificate in English Linguistics rather than in Business English after graduation. Some domestic scholars thought Business English should be attributed to economics rather than linguistics. Should Business English be defined as ESP used in a business environment, or special English for working and communicating in business field? Different opinions lead to different discipline positioning, and thus resulting in misunderstanding of its curriculum setting.

\section{The Role of SPECUlAtive Thinking ABILITY IN BUSINESS ENGLISH TEACHING}

Business English is a branch of English for special purposes. It lays more emphasis on students' practical skills and logical thinking and active discernment. The graduates should have solid basic knowledge of English and business, and analysis, reasoning, evaluation, integration and discrimination ability. In view of this, the research is oriented by the training of various speculative abilities, relies on program content, is supported by self study to construct a speculative thinking ability multi-training model in business English teaching to facilitate the teaching reform of business English and cultivate inter-disciplinary talents with professional theory knowledge, practical ability and speculative thinking ability.

According to the Teaching Requirements of Business English, "practice teaching is an important means to reflect the application characteristics of Business English. The main forms include experiment teaching, professional practice, business program design, academic activities and social 
practice" ${ }^{2}$. Compared with the practice activities listed in the Outline, the practice scope of business English is enlarged, and it is more closely linked with social activities, especially in "business program design". It specifically refers to "students under the guidance of teachers using professional knowledge to complete the design of business programs in accordance with the requirements. Design of business program includes topic selection, information survey, data analysis, writing reports, program design reply and other links". The topic selection, development method, reasoning process and inspection of conclusion are closely related to social life, which is not only beneficial to improve the enthusiasm of the students, and the more important is to help them check their reasoning process through practice and facts at any time. Students' practice effects don't only rely on their language ability, but also rely on abilities in all directions. It includes the speculative thinking ability. Therefore, practice teaching, closely related to social activities is an important way to train students' speculative thinking ability in Business English.

\section{The CONSTRUCTION OF SPECUlative Thinking} Ability Training Model in Business ENGLish TEACHING

This research is designed to construct an effective classroom teaching model and operation mode to realize the flexible application of various teaching models, such as explorative type, discussion type and participation type, and to create a good environment for students' independent thinking, free exploration and innovation, and to train their innovative spirit and practical ability. The paper has explored and summarized a set of teaching strategies for the training of students' speculative thinking ability in Business English to realize the reform and innovation of teaching model.

Through survey and investigation, the author has drawn such enlightenment: in order to cultivate and develop students' speculative thinking ability, it is very important for teachers to have such ability. Firstly, if the teachers think actively and independently, the teachers' words and deeds will subtly influence students to think actively, and to develop the habit of thinking. Secondly, the development of teachers' speculative thinking ability is reflected in all aspects. Teachers should have clear ideas in teaching. Teachers could use simple words and profound views to direct students to further analyze problems when they give answers. They should have their own opinions in teaching. Last, teachers should push through their own limitations, constantly improve their knowledge reserves, and develop their own speculative thinking ability.

In Business English teaching, we should integrate the training of students' speculative thinking ability in all aspects of teaching and strive to build a comprehensive multi-training model. First, raise emotion to guide students. Guide and encourage students and arouse their interests to activate their divergent thinking. Second, rely on the content of program. Teachers can use various teaching activities with cognitive difficulty to develop students' speculative thinking ability when they guide students to learn professional knowledge.

${ }^{2}$ Chen Zhunmin, Wang Lifei. Interpretation of 'Teaching Requirements of Business English in Universities (Tentative). Foreign Languages in China, 2009, 06 (4).
They can design effective strategies to train students' speculative thinking ability according to characteristics of different subjects. Third, be supported by self study. Teachers can encourage students to make their own goal and study methods, and help them get rid of teachers" "authority", encourage them to find, think and solve problems by themselves, and to construct their own speculative model and improve their speculative thinking ability. Last, be supplemented by the improvement of teachers' own speculative thinking ability. Teachers should also improve their own speculative thinking ability when they guide students. They should change their "pattern of authority" in traditional class, reform teaching model, update teaching means to create a good environment for students' independent thinking, free exploration and innovation, and train their innovative spirit and practical ability.

\section{CURRENT PROBlems IN THE CONSTRUCTION OF} SPECUlATIVE THINKING ABILITY MULTI-TRAINING MODEL IN BUSINESS ENGLISH TEACHING

Business English has an advantage in cultivating students' speculative thinking ability, but this does not mean that this process can be easily completed. It is worth mentioning that this challenge exists not only in the domestic higher education. To improve students' speculative thinking ability, we need to solve several problems in the following.

\section{A. The Shortage of Teachers}

The most pressing challenge is the shortage of Business English teachers. As long as Business English students should grasp basic business knowledge, have good language skill and high speculative thinking ability, we need such teachers to achieve this goal. So, Business English teachers should have both good English skill and business knowledge. In the domestic colleges and universities, only some Business English teachers have such education background. Such interdisciplinary teachers are more suitable for the teaching of Business English. However, there are only a few and most of them are in colleges and universities in big cities. On a national scale, the majority of colleges and universities having Business English major cannot solve the problem of teacher shortage in the short term.

\section{B. Students' Thinking Habits}

In Business English teaching, teachers should improve students' speculative thinking ability while teaching them English language skill and business knowledge. Most of students of English majors lack speculative thinking ability. At some point, this is because for a long time English teachers only focus on students' language skill and ignore to train their speculative thinking ability. It is also associated with the difficulty to effectively train students' speculative thinking ability and teach them language at same time. Compared with traditional English majors, Business English students are required to learn business knowledge. The target is to train inter-disciplinary talents both having language skill and business knowledge. It is difficult to achieve this goal. It is more difficult to achieve this goal and train students' speculative thinking ability. Compared with pure language 
disciplines, Business English is more conducive to training students' speculative thinking ability due to its systematicness and logicality. But it doesn't mean students could improve their speculative thinking ability if they grasp professional knowledge well. In the practice of teaching, if teachers don't train students' abilities intentionally, it is easy for students to learn in a purposeless way. They may learn hastily and without thinking, recite words mechanically or study only for getting a good score. So, teachers should help students understand the relevance and logical relationship when they teach students concepts, definitions and business principles. In a sense, Business English is a language discipline, so it is more important to train students to analyze problems from view of business and develop their business thinking ability than to teach specific business knowledge in the courses of Business English. With the industry analysis as an example, any business courses will focus on the introduction to the Five Forces Model of Michael Porter, professor of Harvard University, when teaching this part of knowledge. The Five Forces Model has become a common sense for students of business major due to its global influence. When Business English teachers teach this part of knowledge, they should not only ask students to remember the five forces but also help them experience the relevance among the five forces and the integration of the five forces, as a integrated analysis tool. Only in this way can students learn it as a thinking frame for analyzing problems, rather than take it as five concepts that need to recite. Speculative thinking ability is a transferable ability. When students use the Five Forces Model as a thinking frame, this ability cannot only be used to analyze competitive strategies of enterprises in business program but also help students organize ideas and analyze problems in English disciplines, especially in writing articles. For example, aiming at the topic of "how to explain the difficult inhibition of tobacco consumption", the Five Forces Model has provided a deep and multi-angle thinking frame. It can effectively avoid students arguing only from the angle of "smoking addiction", so that they may write dialectically. This is just an example. Business English involves in professional knowledge of economics, management, laws and other disciplines. It is a huge challenge to help students promote learning of Business English knowledge from the level of "definition" to the level of "thinking frame".

\section{CONCLUSION}

In a word, the cultivation of students' speculative thinking ability is related to their all-round development. The author has made an investigation on speculative thinking ability of English major students in her university and analyzed the influencing factors. As a teacher of a newly-built university, the author has constructed a speculative thinking ability training model for students majoring in Business English to feasibly and effectively train their speculative thinking ability in Business English teaching. However, it is a huge task, and it needs constant exploration and improvement in teaching practice.

\section{REFERENCES}

[1] Xian Peng, Wang Guanfu. Advantages and Challenges of Business English for Developing Students' Speculative Thinking Ability. Foreign Languages, 2014, 30 (4): 167-170.

[2] He Mingxia. New Classroom Construction and Practice of Business English Based on the Training of Speculative Thinking Ability. Daqing Social Sciences, 2016 (2): 147-149.

[3] Zhang Ling. Advantages and Challenges of Business English for Developing Students' Speculative Thinking Ability. Chinese Training, 2015 (18).

[4] Cai Wenjun. CBI Teaching and Evaluation Design of Spoken Business English for the Training of Speculative Thinking Ability. Journal of Jiamusi Occupational College, 2015 (6).

[5] Hu Yueyue, Zhang Yuan. Training of Critical Thinking Ability of Business English Students. Journal of Huaibei Normal University (Philosophy and Social Science Edition), 2016, 37 (3). 